\title{
The Effect Of Levarage, Legislative Measures, Intergovernmental Revenue And Regional Tax Revenue On Regency/City Government Financial In Indonesia
}

\author{
Indi Aprianto \\ Department of Accounting, Univesity Of North Sumatra, Indonesia
}

\begin{tabular}{|c|c|}
\hline ARTICLE INFO & ABSTRACT \\
\hline Article history: & \multirow{4}{*}{$\begin{array}{l}\text { This study aims to determine the effect of leverage, the size of the } \\
\text { legislative, intergovernmental revenue and local tax revenues to } \\
\text { financial performance of districts/cities in Indonesia. The analysis } \\
\text { models is the multiple linear regression analysis. The sample in this } \\
\text { study are } 45 \text { districts/cities in Indonesia. The type of the data in this } \\
\text { research is secondary data. The sampling method is a purposive } \\
\text { sampling method. And the data processing using SPSS. The results } \\
\text { contained in this research is the size of the legislature and local tax } \\
\text { revenue is partially significant effect on the financial performance of } \\
\text { districts/cities in Indonesia. And other result is leverage, the size of } \\
\text { the legislative, intergovernmental revenue and local tax revenues } \\
\text { together has a significant effect on the financial performance of } \\
\text { districts/cities in Indonesia. }\end{array}$} \\
\hline $\begin{array}{r}\text { Received Sep 05, } 2021 \\
\text { Revised Oct 13, } 2021 \\
\text { Accepted Nov 30, } 2021\end{array}$ & \\
\hline Keywords: & \\
\hline $\begin{array}{r}\text { Levarage; } \\
\text { The Size Of Legislative; } \\
\text { Intergovernmental Revenue; } \\
\text { Local Tax Revenues; } \\
\text { Financial Performance. }\end{array}$ & \\
\hline
\end{tabular}

This is an open access article under the CC BY-NC license.

\section{Corresponding Author:}

Indi Aprianto,

Department of Accounting,

University Of North Sumatra, Indonesia,

JI. Dr. Mansur No. 9 Padang Bulan, Kec. Medan Baru, Kota Medan 20222.

Email: indiaprianto@gmail.com

\section{INTRODUCTION}

Leverage is the ratio between debt and equity. As the greater the leverage, the greater the entity's dependence on outside parties because the greater the debt owned by the entity, the lower the financial performance of the entity (Kusumawardani, 2012). Sudarmadji and Sularto (2007) reveal that leverage is a measure used to determine the amount of assets financed by debt.

Legislative size proxied by the number of DPRD members. The Regional People's Representative Council (DPRD) is an institution that has a strategic position and role related to regional financial supervision (Winarna and Murni, 2007). Article 69 paragraph 1 states that the members of the Regency/Municipal DPRD are at least twenty people and a maximum of forty-five people. The large number of DPRD members is also expected to increase supervision of the performance of local governments, so that it has a good impact on increasing the performance of local governments.

Intergovernmental revenue which is proxied by the General Allocation Fund (DAU). Intergovernmental revenue, namely a number of transfers of funds from the center that are deliberately made to finance local government programs (Nam, 2001). The central government hopes that with the transfer, local governments can improve their performance.

Law No. 28 of 2009 states that what is meant by local taxes are mandatory contributions to regions owed by individuals or entities that are coercive under the law, without getting direct compensation and are used for regional needs for the maximum amount. people's prosperity. Local 
taxes, which are one of the important and main sources of PAD, will greatly affect the financial performance of local governments. If the local tax revenue of an area is high or according to the target set, then this shows that the financial performance of an area can be said to be good.

\section{RESEARCH METHOD}

The type of research conducted in this study is causal associative, namely research that aims to determine causal relationships. The unit of analysis in this research is all official websites of local governments in Indonesia. The time horizon used in this study is a cross-sectional study, namely a study conducted with data collected only once, Sekaran (2006).

\subsection{Analysis Method}

The tests used in this study are as follows:

\section{a. Descriptive Analysis}

Descriptive analysis is used to produce an overview of the data that has been collected. Descriptive analysis used in this study is the average (mean), maximum, minimum, and standard deviation.

\section{b. Classic assumption test}

The use of the classical assumption test aims to determine and test the feasibility of the regression model used in this study. Another objective is to ensure that the regression model used has data that are normally distributed, free from autocorrelation, heteroscedasticity and multicollinearity.

\subsection{Normality test}

The data normality test aims to test whether in the regression model, the independent variables, and the dependent variable have a normal distribution and not. A good regression model is to have a normal or close to normal data distribution (Ghozali, 2005) to test the normality of the data can be done in two ways, the first is by looking at the normal probability plot graph, the basis for making decisions from the normal probability plot graph display which refers to Imam Ghozali (2005),

\section{a. Autocorrelation Test}

The autocorrelation test aims to test whether in a linear regression model there is a correlation between the confounding error in a period and the previous period. Autocorrelation problems are often found in time series data or time series because disturbances in a company tend to affect disturbances in the same company in the next period.

\section{b. Heteroscedasticity Test}

Heteroscedasticity test is one of the classical assumptions as a prerequisite for conducting regression analysis. This heteroscedasticity test can be seen based on

\section{c. Multicollinearity Test}

Multicollinearity test aims to test whether the regression model found a correlation between the independent variables (independent). A good regression model should not have a correlation between the independent variables. One way to detect it is by looking at the value of the Variance Inflation Factor (VIF). The cut-off value that is commonly used to indicate the presence of multicollinearity is if the Tolerance value is> 10 (Ghozali, 2007). Provisions in the multicollinearity test:

\section{RESULTS AND DISCUSSIONS}

\subsection{Descriptive Analysis}

Descriptive analysis is used to produce an overview of the data that has been collected. Descriptive analysis used in this study is the average (mean), maximum, minimum, and standard deviation. 
Table 1. Descriptive Statistics Results Descriptive Statistics

\begin{tabular}{cccccc}
\hline & $\mathrm{N}$ & Minimum & Maximum & mean & Std. Deviation \\
\hline Leverage & 45 & .00 & .03 & .0054 & .00752 \\
Legislative Size & 45 & 19.00 & 50.00 & 39.0444 & 8.74371 \\
Intergovernmental Revenue & 45 & .48 & .94 & .7382 & .10792 \\
Tax Income & 45 & 21.49 & 28.52 & 24.8135 & 1.73428 \\
Financial performance & 45 & .01 & 1.24 & .9116 & .24354 \\
Valid N (listwise) & 45 & & & & \\
\hline
\end{tabular}

Source: Results of data processing with SPSS, 2016

Based on table 1 above, it can be seen that the leverage variable has a minimum value of 0.00 and a maximum value of 0.03 . The mean value for leverage is 0.0054 and the value of Std. Deviation 0.00752 with a total of 45 samples of observations. The legislative measure variable has a minimum value of 19 and a maximum value of 50 . The mean value for the legislative measure is 39,044 and the value of Std. Deviation 8,74371 with a total of 45 samples of observations.

The intergovernmental revenue variable has a minimum value of 0.48 and a maximum value of 0.94 . The mean value for intergovernmental revenue is 0.738 and the value of Std. Deviation 0.10792 with a total of 45 samples of observations.

The variable of tax income has a minimum value of 21.49 and a maximum value of 28.52 . The mean value for tax income is 24.8135 and the value of Std. Deviation 1.73428 with a total of 45 samples of observations.

The financial performance variable has a minimum value of 0.01 and a maximum value of 1.24. The mean value for financial performance is 0.9116 and the value of Std. Deviation 0.24354 with a total of 45 samples of observations.

\subsection{Classic assumption test}

The classical assumption test was carried out to ensure that in this study there was no multicollinearity, autocorrelation and heteroscedasticity, and the resulting data had a normal distribution. If there is no multicollinearity, autocorrelation and heteroscedasticity found, then the classical assumption has been fulfilled.

\section{a. Normality test}

The normality test in this study was carried out using the One Sample Kolmogorov-Smirnov Test. In the One-Sample Kolmogorov-Smirnov Test, a data is said to have a normal distribution if the significance value or Asymp value. Sig. (2-tailed) is greater than 0.05 .

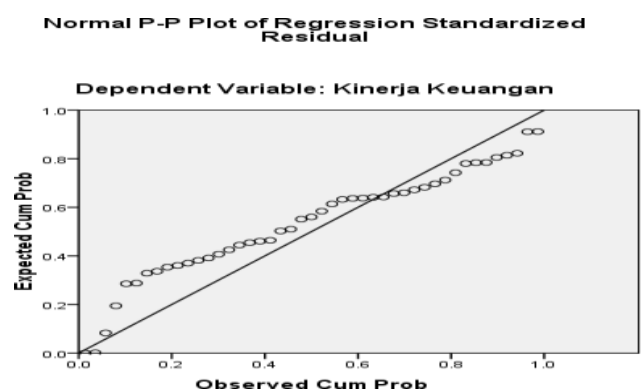

Figure 1. Graph Test Results

If the data distribution is normal, then the line that represents the actual data will follow the diagonal line. Seen from Figure 1 above, the results of the graph test using the PP plot show that the points spread around the diagonal line and their distribution follows the direction of the diagonal line. This graph shows that the regression model is feasible to use because it meets the assumption of normality.

\section{b. Autocorrelation Test}

Autocorrelation test aims to determine whether in a linear regression model there is a correlation between the confounders in period $t$ and errors in period $t-1$ (previous). The analytical tool used is the Durbin Watson Statistical test with the following conditions: 
1) If the Durbin Watson (DW) value lies between the upper limit or Upper Bound (DU) and 4 $\mathrm{DU}$, then the autocorrelation coefficient is zero, meaning there is no autocorrelation.

2) If the DW value is lower than the lower limit or Lower Bound (DL), then the autocorrelation coefficient is greater than zero, meaning that there is a positive autocorrelation.

3) If the value of DW is greater than (4-DL), then the autocorrelation coefficient is smaller than zero, meaning that there is a negative autocorrelation.

4) If the value of DW lies between the upper limit (DU) and the lower limit (DL) or DW lies between (4-DU) and (4-DL), then the results cannot be concluded.

In this study, because it uses $\mathrm{n}=45, \mathrm{k}=5$ so that according to the Durbin Watson table at the level of significance 0.05 it is known that $\mathrm{dl}=1.2874 \mathrm{du}=1.7762,4-\mathrm{du}=2.2238$, and $4-\mathrm{dl}=2.7126$

Table 3. Autocorrelation Test Results Model Summaryb

\begin{tabular}{cccccc}
\hline Model & $\mathrm{R}$ & $\mathrm{R}$ Square & Adjusted R Square & $\begin{array}{c}\text { Std. Error of the } \\
\text { Estimate }\end{array}$ & Durbin-Watson \\
\hline 1 & $.599 \mathrm{a}$ & .358 & .294 & .20459 & 1,807 \\
\hline Source: Results of data processing with SPSS & & &
\end{tabular}

Based on Table 3, the Durbin Watson (DW) value lies between the upper limit or Upper Bound (du) and 4-du, namely $1.7762<1.807<2.2238$. Then the autocorrelation coefficient is equal to zero, which indicates that there is no autocorrelation or there is no correlation between the confounding error in a period and the previous period in the regression model of this study.

\section{c. Heteroscedasticity Test}

Heteroscedasticity test is one of the classical assumptions as a prerequisite for conducting regression analysis. This heteroscedasticity test can be seen based on a scatterplot, but the heteroscedasticity test using a scatterplot is very weak because it only relies on visual analysis. To get certainty, it is necessary to test the hypothesis by using the Glejser test.

The Glejser test proposes to regress the absolute residual value as the dependent variable with the independent variable in the study, so that the Glejser test results are more real than the scatterplot which is only assessed through its visuals. After regressing by entering the absolute value of the residual as the dependent variable, the following SPSS output is produced.

Table 4. Glejser Test Results Coefficientsa

\begin{tabular}{|c|c|c|c|c|c|c|c|c|}
\hline \multicolumn{2}{|r|}{ Model } & \multicolumn{2}{|c|}{$\begin{array}{l}\text { Unstandardized } \\
\text { Coefficients }\end{array}$} & \multirow{2}{*}{$\begin{array}{l}\text { Standardize d } \\
\text { Coefficients } \\
\text { Beta }\end{array}$} & \multirow[t]{2}{*}{$\mathrm{t}$} & \multirow[t]{2}{*}{ Sig. } & \multicolumn{2}{|c|}{ Collinearity Statistics } \\
\hline & & $\mathrm{B}$ & Std. Error & & & & Tolerance & VIF \\
\hline \multirow[t]{5}{*}{1} & (Constant) & -.379 & .399 & & -.949 & .348 & & \\
\hline & Leverage & $-1,707$ & 2.844 & -.087 & -.600 & .552 & .986 & 1.014 \\
\hline & Legislative Size & -.006 & .003 & -.373 & -2.415 & .020 & .857 & 1.166 \\
\hline & $\begin{array}{l}\text { Intergovernmental } \\
\text { Revenue }\end{array}$ & .170 & .212 & .123 & .800 & 429 & .862 & 1.161 \\
\hline & Tax Income & .026 & .013 & 299 & 1,918 & .062 & .842 & 1.188 \\
\hline
\end{tabular}

a. Dependent Variable: ABS_RES_1

Based on the table above, it can be seen the significant value of each independent variable after regress with the absolute value of the residual as the dependent variable. Decision making in the Glejser test is if the significant value is $>0.05$ then $\mathrm{HO}$ is rejected or there is no heteroscedasticity in this research model, but on the contrary if the significant value is $<0.05$ then $\mathrm{H} 0$ is accepted or heteroscedasticity occurs in this research model.

Based on the results of the SPSS output above, it can be seen that the significant value of each variable is 0.552 for leverage, 0.020 for legislative size, 0.429 for intergovernmental revenue and 0.062 for tax revenue. Of the four variables studied, only the legislative size has heteroscedasticity in the data, with a significant value of $0.020<0.05$, this happens because the number of legislative 
sizes in each region (district/city) tends to be the same. Meanwhile, the other variables are free from this heteroscedasticity symptom.

\section{d. Multicollinearity Test}

This test aims to test whether the regression model found a correlation between the independent variables (independent). A good regression model should not have a correlation between the independent variables. Provisions in the multicollinearity test:

If the Tolerance value $>0.1$ and $\mathrm{VIF}<10$, it can be interpreted that there is no multicollinearity in the study.

If the value of Tolerance $<0.10$ and VIF $>10$, it can be interpreted that there is a multicollinearity disorder in the study.

Table 5. Multicollinearity Test Results Coefficientsa

\begin{tabular}{|c|c|c|c|}
\hline \multirow{2}{*}{\multicolumn{2}{|c|}{ Model }} & \multicolumn{2}{|c|}{ Collinearity Statistics } \\
\hline & & Tolerance & VIF \\
\hline \multirow[t]{5}{*}{1} & (Constant) & & \\
\hline & Leverage & .986 & 1.014 \\
\hline & Legislative Size & .857 & 1.166 \\
\hline & Intergovernmental Revenue & .862 & 1.161 \\
\hline & Tax Income & .842 & 1.188 \\
\hline
\end{tabular}

Based on Table 5, it can be concluded that there is no symptom of multicollinearity in the interaction of leverage, legislative size, intergovernmental revenue and tax revenues on financial performance because each tolerance value is above 0.10 and the VIF value is below 10 .

\subsection{Hypothesis Test}

\section{a. Multiple Linear Regression Analysis}

The analytical technique used in this study is multiple linear regression analysis to describe the effect of leverage, legislative size, intergovernmental revenue and tax revenue on financial performance. The results of the regression analysis can be seen in the following table:

Table 6. Multiple Linear Regression Analysis Results Coefficientsa

\begin{tabular}{|c|c|c|c|c|c|c|c|c|}
\hline \multirow{2}{*}{\multicolumn{2}{|c|}{ Model }} & \multicolumn{2}{|c|}{$\begin{array}{l}\text { Unstandardized } \\
\text { Coefficients }\end{array}$} & \multirow{2}{*}{$\begin{array}{c}\text { Standardized } \\
\text { Coefficients } \\
\text { Beta }\end{array}$} & \multirow[t]{2}{*}{$t$} & \multirow[t]{2}{*}{ Sig. } & \multicolumn{2}{|c|}{ Collinearity Statistics } \\
\hline & & $\mathrm{B}$ & Std. Error & & & & Tolerance & VIF \\
\hline \multirow[t]{5}{*}{1} & (Constant) & 1,702 & .579 & & 2,939 & .005 & & \\
\hline & Leve & -2.839 & 4.129 & -.088 & -.688 & .496 & 986 & 1.01 \\
\hline & Legislative Size & .016 & .004 & .561 & 4.105 & .000 & .857 & 1.16 \\
\hline & Intergovernmental Revenue & .094 & .308 & .041 & .304 & .763 & .862 & 1.161 \\
\hline & Tax Income & -.059 & .019 & -.417 & -3.024 & .004 & .842 & 1.188 \\
\hline
\end{tabular}

Source: Results of data processing with SPSS, 2016

\section{b. F Statistical Test}

The $\mathrm{F}$ test is used to see the effect of all independent variables (leverage, legislative size, intergovernmental revenue and tax revenue) on the dependent variable (financial performance) simultaneously. This effect needs to be tested to see whether this regression model can be continued by performing a t-test (partial) or not.

If the results of the $\mathrm{F}$ test have a positive effect, this regression model can be continued by performing a t test (partial test). On the other hand, if it has no effect, then the t-test (partial test) cannot be carried out, because all independent variables do not affect the dependent variable. The following is a table of $\mathrm{F}$ test results. 
Table 7. F Test Results

ANOVAb

\begin{tabular}{ccccccc}
\hline & Model & Sum of Squares & $\mathrm{df}$ & Mean Square & $\mathrm{F}$ & Sig. \\
\hline 1 & Regression & .935 & 4 & .234 & 5.587 & $.001 \mathrm{a}$ \\
& Residual & 1,674 & 40 & .042 & & \\
& Total & 2.610 & 44 & & & \\
& & &
\end{tabular}

Source: Results of data processing with SPSS, 2016

Based on the table above, it can be seen that the $F$ test results show a significant value of 0.001 which is smaller than 0.05 . This means that the $F$ test results show the variable

independent jointly (simultaneously) has a significant influence on the dependent variable, namely financial performance. To see what independent variables have an effect on financial performance, a t-test (partial test) was conducted.

\section{c. Statistical Test}

The t-statistical test basically shows how far the influence of one independent variable individually in explaining the dependent variable. The hypothesis is formulated as follows:

$\mathrm{HO}: \mathrm{Xi}=0$, meaning that there is no significant effect of the independent variable on the dependent variable.

$\mathrm{H} 1: \mathrm{Xi}=0$, meaning that there is a significant effect of the independent variable on the dependent variable.

Table 8. T-Test Results (Partial) Coefficientsa

\begin{tabular}{|c|c|c|c|c|c|c|}
\hline \multicolumn{2}{|r|}{ Model } & \multicolumn{2}{|c|}{ Unstandardized Coefficients } & \multirow{2}{*}{$\begin{array}{c}\text { Standardized } \\
\text { Coefficients } \\
\text { Beta } \\
\end{array}$} & \multirow[t]{2}{*}{$\mathrm{T}$} & \multirow[t]{2}{*}{ Sig. } \\
\hline & & B & Std. Error & & & \\
\hline \multirow[t]{5}{*}{1} & (Constant) & 1,702 & .579 & & 2,939 & .005 \\
\hline & Leverage & -2.839 & 4.129 & -.088 & -.688 & .496 \\
\hline & Legislative Size & .016 & .004 & .561 & 4.105 & .000 \\
\hline & Intergovernmental Revenue & .094 & .308 & .041 & .304 & .763 \\
\hline & Tax Income & -.059 & .019 & -.417 & -3.024 & .004 \\
\hline
\end{tabular}

Based on Table 8, the results of the regression test analysis state that leverage and intergovernmental revenue do not have a partial (individual) effect on financial performance. However, the size of the legislature and tax revenues partially have a positive and significant effect on financial performance. Leverage has a significance value of $t$ of $0.496>0.05$, meaning that partial leverage has no significant effect on financial performance. The size of the legislature has a significance value of $t$ of $0.000<0.05$, meaning that the size of the legislature partially has a significant effect on financial performance. Intergovernmental revenue has a significance value of $t$ of $0.763>$ 0.05 , meaning that partially intergovernmental revenue has no significant effect on financial performance.

\section{c. Coefficient of Determination Test}

The coefficient of determination (R2) essentially measures how far the model's ability to explain the variation of the dependent variable. The value range is 0 to 1 , if the value of $R 2$ is small, it means that the ability of the independent variables in explaining the variation of the dependent variable is very limited, and conversely if $R 2$ is large (close to the value of 1), it means that the ability of the independent variables to explain the variation of the dependent variable is large. The value of R2 can be seen in table 9 below.

Table 9. Coefficient of Determination Test Results (R2) Model Summaryb

\begin{tabular}{cccccc}
\hline Model & $\mathrm{R}$ & $\mathrm{R}$ Square & Adjusted R Square & $\begin{array}{c}\text { Std. Error of the } \\
\text { Estimate }\end{array}$ & Durbin-Watson \\
\hline 1 & $.599 \mathrm{a}$ & .358 & .294 & .20459 & 1,807 \\
\hline Source: Results of data processing with SPSS, 2016 & &
\end{tabular}

Source: Results of data processing with SPSS, 2016 
Based on table 9 , the value of $R$ Square (R2) is 0.358 , which means 0.358 or $(35.8 \%)$ the independent variables, namely leverage, legislative size, intergovernmental revenue and tax revenue are able to explain financial performance. While the remaining $64.2 \%$ is influenced or explained by other variables that are not included in the research model.

\section{CONCLUSION}

Leverage does not have a significant effect on the financial performance of district/city governments in Indonesia. The size of the legislature has a significant effect on the financial performance of district/city governments in Indonesia. Intergovernmental revenue does not have a significant effect on the financial performance of district/city governments in Indonesia. Local tax revenues have a significant effect on the financial performance of district/city governments in Indonesia. Leverage, the size of the legislature, intergovernmental revenue and local tax revenues simultaneously have a significant effect on the financial performance of district/city governments in Indonesia.

\section{REFERENCES}

Accounting Volume 1 IFRS Edition. Unites States of America: John Wiley and Sons, Inc.

Afiah, Nunuy Nur. 2009. Pengaruh Kompetensi Anggota DPRD Dan Kompetensi Aparatur Pemerintah Daerah Terhadap Pelaksanaan System Informasi Akuntansi. Working Paper In Accounting And Finance Padjajaran University.

Agus, Nuniek Avianti.2000. Mudah Belajar MATEMATIKA. Buku Sekolah Elektronik (BSE). Pusat Perbukuan depdiknas.

Alfarisi, Salman. 2009. Pengaruh Pajak Daerah, Retribusi Daerah, Dan Dana Perimbangan Terhadap Kinerja Keuangan Pemerintah Daerah (Studi Empiris Pada Kabupaten Dan Kota Di Provinsi Sumatera Barat). Jurnal. Fakultas Ekonomi Universitas Negri Padang.

Almilia, L. Spica dan Retrinasari, Ikka. 2007. Analisis Pengaruh Karateristik Perusahaan terhadap Kelengkapan Pengungkapan dalam Laporan Tahunan Perusahaan Manufaktur yang terdaftar di BEJ. Makalah disajikan dalam Seminar Nasional Inovasi dalam Menghadapi Perubahan Lingkungan Bisnis, Fakultas Ekonomi Universitas Trisakti, Jakarta, 9 Juni 2009.

Anzarsari, Desy.2014. Pengaruh Karakteristik Pemerintah Daerah Terhadap Kinerja Pemerintah Daerah (Studi Empiris Pada Kabupaten/Kota Se- Jawa Tengah). Skripsi. Fakultas Ekonomi Dan Bisnis Program Studi Akuntansi Universitas Muhammadiyah Surakarta

Azhar, Muhammad Karya Satya. 2008. Analisa Kinerja Keuangan pemerintah Daerah Kabupaten/Kota Sebelum dan Setelah Otonomi Daerah. Tesis Pascasarjana Universitas Sumatera Utara dipublikasikan.

Bastian, Indra. 2006. Akuntansi Sektor Publik. Jakarta: Erlangga.

Chariri, Anis dan Imam Ghozali. 2003. Teori Akuntansi. Semarang : BP Undip Choiriyah, Umi. 2010. Information Gap Pengungkapan Lingkungan Hidup Di

Indonesia. Skripsi Fakultas Ekonomi Universitas Sebelas Maret.Tidak dipublikasi.

Chow, C.W., Ganulin, D., Haddad, K. and Williamson, J. 1998. The balanced scorecard: a potent tool for energizing and focusing health-care organization management. Journal of Health-care Management.

Cohen, Sandra.2006. Identifying the Moderator Factor of Financial Performance in Greek Municipal. Annuall Conference. $5^{\text {th }}$. HFAA. Thessaonica.

Fitriyani, Ismi Rizky dan Partolo, Suryo 2009. Pengaruh Pendapatan Asli Daerah dan Belanja Pembangunan Terhadap Rasio Kemandirian dan Pertumbuhan Ekonomi. Penelitian Keuangan Akuntansi Sektor Publik II Badan Litbang Departemen Dalam Negeri, Bidakara, 2-3 Juni 2009.

Florida, Asha. 2008. Pengaruh Pendapatan Asli Daerah Terhadap Kinerja Keuangan Pemerintah Kabupaten Dan Kota Di Provinsi Sumatera Utara. Skripsi. Medan: Fakultas Ekonomi Universitas Sumatera Utara.

Ghozali dan Chariri, 2007. Teori Akuntansi. Semarang : Badan Penerbit Undip. Giligan, Thomas W and Matsusaka, John G. 2001. Fiscal Policy, Legislature Size,

and Political Parties: Evidence from State and Local Governments in the First Half of the 20th Century. National Tax journal. Vol. 54: 57-82.

Greiling, Dorothea. 2005. Performance Measurement in the Public Sector: the German Experience. International Journal of Productivity and Performance Management, (Online), Vol. 54 Iss: 7 ,

Groves, Sanford M, S.Godsey, dan Shulman. 2001. Financial Indicator Forlocal Government. Public Finance International City Management Association. 9

Gujarati, Damodar N. 1993. Ekonometrika Dasar, cetakan ketiga, Erlangga, Jakarta

Halachmi, Arie. 2005. Performance measurement is only one way of managing performance. International Journal of Productivity and Performance Management. Vol. 54: 502-516.

Halim, Abdul. 2007. Akuntansi Sektor Publik: Akuntansi Keuangan Daerah. Jakarta: Salemba Empat. 
Hamzah, Ardi. 2008. Analisa Kinerja Keuangan terhadap Pertumbuhan Ekonomi, Pengangguran, dan Kemiskinan: Pendekatan Analisis Jalur (Studi pada 29 Kabupaten dan 9 Kota di Propinsi Jawa Timur Periode 2001-2006). Jurnal. Universitas Trunojoyo Madura.

Handra, Hefrizal dan Maryati, Sri. 2009. Analisis Pendapatan Asli Daerah (PAD) Bukan Pajak Pemerintah Propinsi Sumatra Barat. Konferensi Penelitian Keuangan Sektor Publik II Badan Litbang Departemen Dalam Negeri.

Haniffa, R.M. dan T.E. Cooke, 2005, "The Impact of Culture and Governance on Corporate Social Reporting", Journal of Accounting and Public Policy 24, pp. 391-430.

Julitawati, Ebit, Darwanis, dan Jalaluddin. 2012. Pengaruh Pendapatan Asli Daerah dan Dana Perimbangan terhadap Kinerja Keuangan Pemerintah Kabupaten/Kota di Provinsi Aceh. Jurnal Akuntansi Pascasarjana Universitas Syiah Kuala, Vol. 1, No.1: 1-15.

Kieso, E. Donald, Weygandt, Jerry, and Warfield, Terry. 2011. Intermediate

Kusumawardani, Media. 2012. Pengaruh Size, Kemakmuran, Ukuran Legislatif, Leverage terhadap Kinerja Keuangan Pemerintah Daerah di Indonesia. Accounting Analysis Journal 1 (1).

Mahsun, Mohamad. 2006. Pengukuran Kinerja Sektor Publik. Yogyakarta: BPFE Maiyora, Gita.2015. Pengaruh Karakteristik Pemerintah Daerah Terhadap Kinerja

Keuangan Pemerintah Darah Kabupaten/Kota (Studi Empiris Kabupaten/Kota Di Pulau Sumatera). Jurnal. FEKON vol 2 no 2oktober 2015. Universitas Riau.

Mandell, Lee M. 1997. Performance Measurements and Management Tools in North Carolina Local Goverment. Public Administration Quarterly; Spring 1997; Vol. 21: 96.

Mardiasmo. 2009. Akuntansi Sektor Publik. Yogyakarta: Andi.

Nam, Chan Woon dan Parsche, Rudiger. 2002. Looking for Appropriate forms of Intergovernmental Transfers for Municipalities in Transition Economies. Makalah disajikan dalam 42nd Congress of the European Regional Science Association (ERSA), Dortmund, 27-31 Agustus 2002.

Nolan, James F, Moore, Adrian, dan Segal, Geoffrey. 2003. Putting out the trash: measuring municipal service efficiency in U.S. cities. Working Paper Series. SSRN September

Noor, Hasanuddin, 2009. Psikometri Aplikasi Penyusunan Instrumen Pengukuran Perilaku. Bandung: Fakultas Psikologi UNISBA.

Patrick, P. A. 2007. The Determinant of Organizational Inovativeness: The Adoption of GASB 34 in Pennsylvania Local Government. Unpublished Ph.D Dissertation. Pennsylvania: The Pennsylvania State University.

Perwitasari, Citra. 2010. The Influence of Financial Performance to the Level of Accountability Disclosure of Indonesia's Local Government. Tesis Universitas Sebelas Maret Surakarta.

Rochmah, Nur, Siti.2015. FAKTOR-FAKTOR YANG MEMPENGARUHI KINERJA KEUANGAN PEMERINTAH DAERAH (Studi Emipiris

Pada Kota dan Kabupaten di Provinsi Jawa Tengah Tahun 2009-2012). Skripsi. Fakultas Ekonomi dan Bisnis Universitas Muhammadiyah Surakarta

Sadjiarto, Arja. 2000. Akuntabilitas dan Pengukuran Kinerja Pemerintahan. Jurnal Akuntansi dan Keuangan. Vol. 2 (2): 138-150.

Sekaran, Uma dan Bougie, Roger. 2010. Research Methods for Business-A Skill Building Approach-5th Edition. United Kingdom: John Wiley\&Sons Ltd.

Sesotyaningtyas, Mirna. 2012. Pengaruh Leverage, Ukuran Legislatif, Intergovernmental Revenue Dan Pendapatan Pajak Daerah Terhadap Kinerja Keuangan Pemerintah Daerah. Jurnal Accounting analysis Fakultas Ekonomi Universitas Negeri Semarang.

Setyaningrum, Dyah \& Febriyani Syafitri. 2012. Analisis Pengaruh Karakteristik Pemerintah Daerah Terhadap Tingkat Pengungkapan Laporan Keuangan. Jurnal Akuntansi dan Keuangan Indonesia, Volume 9, No.2 Tahun 2012.

Sudarmadji, A. Murdoko, dan Sularto, Lana. 2007. Pengaruh Ukuran Perusahaan, Profitabilitas, Leverage dan Tipe kepemilikan Perusahaan Terhadap Luas Voluntary Disclosure Laporan Keuangan Tahunan, Jakarta, Auditorium Kampus Gunadarma, 21-22 Agustus 2007.

Suhardjanto, Djoko., Rusmin, Mandasari., Putriesti., dan Brown, Alistair. 2010. 'Mandatory Disclosure Compliance and Local Government Charactheristics: Evidence From Indonesian Municipalities'. Journal Public Policy January 2010.

Sumarjo, Hendro. 2010. Pengaruh Karakteristik Pemerntah Daerah Terhadap Kinerja Keuangan Pemerintah Daerah. Skripsi Fakultas Ekonomi Universitas Sebelas Maret.

Tim Penyusun STAN. 2007. Dasar-Dasar Audit Internal Sektor Publik. Modul Program Pendidikan Non Gelar Auditor Sektor Publik. STAN : Jakarta.

Wahid Sulaiman, 2004, Analisis Regresi Menggunakan SPSS, Yogyakarta : Andi Offset.

Weill, Laurent. 2003. Leverage and Corporate Performance: A Frontier Efficiency Analysis on European Countries. Working Paper. Working Paper Series. SSRN May. 
Winarna, J and Murni, S. 2007. Pengaruh Personal Background, Political Background, dan Pengetahuan Dewan Tentang Anggaran Terhadap Peran DPRD Dalam Pengawasan Keuangan Daerah (Studi Kasus Di Karesidenan Surakarta Dan Daerah Istimewa Yogyakarta Tahun 2006). Simposium Nasional Akuntansi $\mathrm{X}$.

Wiratraman, R. Herlambang Perdana. 2009. Paradigma Hukum dan Demokratisasi dalam Pengelolaan Keuangan Daerah. www.google.com.

Wood, L. 1998. Local Government Dollars \& Sense (Rancho Palos Verdes, CA.: Training Shoppe). 